\title{
Pengaruh Kepatuhan Diet, Aktivitas Fisik dan Pengobatan dengan Perubahan Kadar Gula Darah pada Pasien Diabetes Mellitus Suku Rejang
}

\author{
Almaini $^{1}$, Hendri Heriyanto ${ }^{2}$ \\ ${ }^{1,2}$ Prodi Keperawatan Curup, Poltekkes Kemenkes Bengkulu, Curup, Indonesia \\ almaini.10@gmail.com
}

\begin{abstract}
Diabetes mellitus (DM) is a chronic disease characterized by blood glucose levels exceeding normal and impaired metabolism of carbohydrates, fats and proteins due to a relative or absolute deficiency of insulin hormones. This study aimed to determine the relationship between dietary compliance, physical activity, and adherence to taking medication with blood sugar levels when in patients with type 2 diabetes mellitus. This type of research was analytical with a cross-specific approach that uses a sample of 46 Rejang tribal diabetes mellitus patients who come to Curup Health Center, Prumnas Health Center and Delima Village Health Center during the period of August to October 2018 which met the criteria for inclusion and exclusion. The instruments used were food recall forms, questionnaires, medical records and glucometers. The results of the study were processed by bivariate analysis using the chi square test and multivariate analysis with logistic regression test. The results of the bivariate statistical test dietary compliance variable $p=0.001 \mathrm{OR}=15,343, C I=3,327-67,636$, and the medication adherence variable $p=0,035, O R=4,038, C I$ 1,061-15,370. There was a significant relationship between diet compliance, adherence to taking medication with blood sugar levels when in patients with diabetes melititus Rejang tribe Rejang Lebong District. DM patients are expected to always adhere to diet, physical activity and medication treatment.
\end{abstract}

Keywords: physical activity, diabetes mellitus, diet, adherence, medication

\begin{abstract}
Abstrak
Diabetes Mellitus (DM) merupakan suatu penyakit menahun yang disebabkan kekurangan hormon insulin secara relatif maupun absolut dan ditandai dengan peningkatan kadar glukosa darah dan gangguan metabolisme karbohidrat, lemak dan protein. Penelitian ini bertujuan untuk mengetahui hubungan antara kepatuhan diet, aktivitas fisik, dan kepatuhan minum obat dengan kadar gula darah sewaktu pada pasien diabetes melitus tipe 2. Jenis penelitian ini analitik dengan pendekatan Cross sectional study yang menggunakan sampel sebanyak 46 pasien diabetes melitus suku Rejang yang datang ke Puskesmas Curup, Puskesmas Prumnas dan Puskesmas Kampung Delima selama periode bulan Agustus sampai dengan bulan Oktober 2018 yang memenuhi kriteria inklusi dan eksklusi. Instrumen yang digunakan adalah formulir food recall, kuesioner, catatan medik, dan glukometer. Hasil penelitian diolah dengan analisis bivariat menggunakan uji chi square dan analisis multivariat dengan uji regresi logistik. Hasil uji statistik bivariat variabel Kepatuhan diet $p=0,001$ OR=15,343, $C I=3,327$ 67,636, dan variabel kepatuhan minum obat $p=0,035, O R=4,038, C I: 1,061-15,370$. Terdapat hubungan yang bermakna antara kepatuhan diet, kepatuhan minum obat dengan kadar gula darah sewaktu pada pasien DM suku Rejang Kabupaten Rejang Lebong. Diharapkan pasien DM untuk selalu mematuhi diet, aktivitas fisik dan pengobatan.
\end{abstract}

Kata kunci:, aktivitas fisik, diabetes mellitus, diet, kepatuhan, obat

Jurnal Keperawatan Raflesia, Volume 1 Nomor 1, Mei 2019

ISSN: 2656-6222, DOI 10.33088/jkr.vlil.393

Available online: https://jurnal.poltekkes-kemenkes-bengkulu.ac.id/index.php/jkr 


\section{PENDAHULUAN}

Diabetes Mellitus (DM) merupakan suatu penyakit kronis dan progresif yang ditandai dengan ketidakmampuan tubuh dalam metabolisme karbohidrat, lemak dan protein sehingga menimbulkan hiperglikemia atau kadar glukosa darah melebihi normal (Black \& Hawks, 2010). Menurut Aditama (2013) terdapat beberapa faktor yang membuat seseorang terkena DM antara lain faktor ras atau etnis, usia, obesitas, kurang gerak badan, keturunan, kehamilan, infeksi, stress, dan obat obatan.

Jumlah pasien DM terus meningkat setiap tahunnya. Berdasarkan laporan International Diabetes Federation (IDF), pada tahun 2011 terdapat 366 juta penderita DM, dan diperkirakan meningkat menjadi 552 juta pada tahun 2030, yang mayoritas terjadi pada penduduk di negara miskin dan negara berkembang (Whiting, Guariguata, Weil, \& Shaw, 2011). Di Indonesia, diperoleh data terjadi peningkatan prevalensi DM berdasarkan pemeriksaan darah pada penduduk umur $\geq 15$ tahun. Prevalensi DM pada tahun 2013 sebesar 6,9 persen, tahun 2018 meningkat menjadi 10,9\% (Balitbangkes Kemenkes RI, 2018). Pasien yang menderita penyakit DM di Propinsi Bengkulu diperkirakan mencapai 417.600 orang atau sekitar 8,7\%. Kabupaten Rejang Lebong, kasus DM menduduki ranking ke 6 dari 35 jenis penyakit yaitu sebanyak yaitu 4.573 penderita (Dinas Kesehatan Bengkulu, 2014). Hal ini menunjukkan penyakit DM menjadi salah satu ancaman bagi kesehatan.

Manajemen DM bertujuan untuk mempertahankan kadar glukosa darah normal dengan melakukan diet, latihan atau aktifitas fisik dan penggunaan obat-obatan oral ataupun insulin Dengan menjalankan diet yang tepat dapat meningkatkan kontrol metabolisme melalui perubahan kebiasaan makan, sehingga pasien DM akan mendapatkan asupan nutrisi yang cukup dan konsisten, kadar glukosa darah terkontrol dan berat badan ideal (Black \& Hawks, 2010). Aktifitas fisik dapat mengontrol kadar gula darah, menurunkan risiko penyakit kardiovaskular, menurunkan berat badan, dan meningkatkan kesejahteraan (American Diabetes Association, 2019). Obat-obatan digunakan ketika pasien tidak mampu mempertahankan kadar glukosa darah normal dengan melaksanakan diet dan latihan fisik.

Diabetes mellitus dapat menimbulkan berbagai komplikasi pada penderitanya apabila tidak dimanajemen dengan baik. Berdasarkan Centers for Disease Control and Prevention, National Diabetes Statistics Report (2017), berbagai komplikasi DM muncul akibat dari kebiasaan merokok, obesitas, kurang gerak, tekanan darah tinggi, kolesterol dan kadar glukosa darah yang tinggi. Keadaan ini menyebabkan pasien harus menjalani hospitalisasi, mengeluarkan biaya, kondisi gawat darurat bahkan kematian. Partisipasi aktif pasien, keluarga dan masyarakat sangat diperlukan untuk pemberdayaan penyandang DM. Selain itu dibutuhkan pendidikan kesehatan yang komprehensif dan upaya peningkatan motivasi tim kesehatan dalam mendampingi pasien untuk mencapai perubahan perilaku sehat (PERKENI, 2011).

Atas dasar permasalahan tersebut diatas peneliti tertarik untuk melakukan kajian lebih lanjut tentang pengaruh dari kepatuhan menjalankan program diet, 
aktivitas fisik dan program pengobatan terhadap perubahan kadar gula darah penderita DM Tipe II suku rejang di Kabupaten Rejang Lebong.

\section{METODE}

Penelitian ini menggunakan metode cross sectional study. Penelitian dilaksanakan di Puskesmas dalam wilayah Kecamatan Curup Kota, Curup Tengah, Curup Selatan, dan Curup Timur. Sampel dipilih dengan teknik purposive sampling dari populasi pasien diabetes mellitus suku Rejang yang berkunjung ke Puskesmas Curup, Puskesmas Prumnas, dan Puskesmas Kampung Delima Kabupaten Rejang Lebong pada periode bulan Agustus sampai dengan Oktober tahun 2018, dengan jumlah sampel 46 orang. Pemilihan wilayah puskesmas ini atas pertimbangan kemudahan akses dan proporsi jumlah penduduk di wilayah Puskesmas tersebut cukup tinggi.

Instrumen penelitian yang digunakan dalam penelitian ini adalah formulir food recall yang digunakan untuk mendapatkan informasi tentang kepatuhan pasien dalam menjalankan aturan diet sekaligus mengetahui jumlah makanan yang dikonsumsi 24 jam terakhir (USU, 2014), kuesioner aktivitas fisik untuk mendapatkan informasi tentang kepatuhan pasien menjalankan aktivitas fisik dan kuesioner pil count regimen digunakan untuk mengetahui kepatuhan pasien minum obat antidiabetik sesuai dengan aturan dalam catatan medik dokter puskesmas, alat glukometer untuk mengukur kadar glukosa darah sewaktu, catatan medik pasien yang berobat di Puskesmas Curup, Puskesmas Perumnas dan Puskesmas Kampung
Delima yang berkunjung pada periode bulan juni sampai agustus tahun 2018. Adapun kriteria inklusi dalam penelitian ini adalah pasien DM tipe 2 yang berkunjung ke Puskesmas Curup, Puskesmas Perumnas dan Puskesmas Kampung Delima sedangkan kriteria eksklusi adalah pasien yang tidak mempunyai catatan medik yang lengkap di Puskesmas.

Pengolahan data meliputi tahapan pengeditan, pengkodingan, dan pengambilan nilai (scoring). Data dari formulir food recall akan dihitung jumlah kalori yang dikonsumsi dalam 24 jam, kemudian dibandingkan dengan catatan medik tentang jumlah kalori yang anjurkan oleh dokter. Jika jumlah kalori yang dikonsumsi berada dalam rentang yang dianjurkan dokter maka pasien dikatakan patuh terhadap diet. Data dari kuesioner aktivitas fisik akan dinilai dan dibandingkan dengan jenis aktivitas fisik yang dianjurkan oleh dokter puskesmas, jika aktivitas fisik sesuai dengan anjuran dokter maka pasien dikatakan patuh melakukan aktivitas. Data dari formulir pil count akan dibandingkan dengan catatan medik dokter tentang aturan minum obat, jika sesuai dengan aturan dari catatan medik maka pasien dikatakan patuh minum obat.

Analisis data meliputi analisis univariat pada data yang berskala kategorik seperti kepatuhan diet, kepatuhan aktivitas fisik dan kepatuhan minum obat, dan data yang berskala nominal seperti golongan umur dan jenis kelamin akan dinyatakan sebagai distribusi frekuensi dan persentase. Analisis bivariat berupa uji hipotesis antara variabel bebas yaitu kepatuhan diet, kepatuhan aktivitas dan kepatuhan minum 
obat dengan variabel terikat yaitu perubahan kadar gula darah sewaktu, di analisis menggunakan uji beda proporsi $c h i$ square, sedangkan untuk mengetahui besaran faktor risiko akan dihitung odd ratio. Analisis multivariat dilakukan untuk mengetahui pengaruh dari antar variabel, menggunakan statistik regresi logistik (Dahlan, 2012).

\section{HASIL}

Penelitian ini dilaksanakan di wilayah Puskesmas dalam kota Curup dengan proporsi responden sebagai berikut: Puskesmas Curup (34,8\%), Puskesmas Prumnas $(43,5 \%)$ dan Puskesmas Kampung Delima $(21,7 \%)$.

Tabel 1. Proporsi responden berdasarkan golongan umur dan Jenis Kelamin

\begin{tabular}{cllll}
\hline Golongan & \multicolumn{2}{c}{ Laki-laki } & \multicolumn{2}{c}{ Perempuan } \\
\cline { 2 - 5 } \multicolumn{1}{c}{ umur } & \multicolumn{1}{c}{$\mathrm{n}$} & \multicolumn{1}{c}{$\mathrm{n}$} & $\%$ \\
\hline $21-40$ & 1 & 5,0 & 4 & 15,3 \\
$41-60$ & 14 & 70,0 & 13 & 50,0 \\
$>60$ & 5 & 25,0 & 9 & 34,7 \\
\hline
\end{tabular}

Tabel 1. menunjukkan proporsi responden berdasarkan jenis kelamin sebagian besar adalah laki-laki dengan golongan umur 4160 tahun $(70 \%)$.
Tabel 2. Proporsi Karakteristik Responden Berdasarkan Tingkat Pendidikan

\begin{tabular}{lcc}
\hline Tingkat Pendidikan & $\mathrm{n}$ & $\%$ \\
\hline Sekolah Dasar & 8 & 17,4 \\
Sekolah Menengah Pertama & 9 & 19,6 \\
Sekolah Menengah Atas & 22 & 47,8 \\
Perguruan Tinggi & 7 & 15,2 \\
\hline
\end{tabular}

Tabel 2. menunjukkan bahwa sebagian besar responden dalam penelitian ini adalah berpendidikan Sekolah Menengah Atas $(47,8 \%)$.

Tabel 3. Karakteristik Responden berdasarkan tingkat kepatuhan Diet, aktivitas fisik, dan minum obat

\begin{tabular}{|c|c|c|}
\hline Variabel & $\mathrm{n}$ & $\%$ \\
\hline \multicolumn{3}{|l|}{ Kepatuhan Diet } \\
\hline Patuh & 22 & 47,8 \\
\hline Tidak Patuh & 24 & 52,2 \\
\hline Kepatuhan Aktivitas & & \\
\hline \multicolumn{3}{|l|}{ Fisik } \\
\hline Patuh & 19 & 41,3 \\
\hline Tidak Patuh & 27 & 58,7 \\
\hline \multicolumn{3}{|l|}{ Kepatuhan Minum Obat } \\
\hline Patuh & 27 & 58,7 \\
\hline Tidak Patuh & 19 & 41,3 \\
\hline
\end{tabular}

Tabel 3. menunjukkan bahwa sebagian besar responden tidak patuh pada diet $(52,2 \%)$, sebagian besar $(58,7 \%)$ tidak patuh pada aktivitas fisik, dan sebagian besar $(58,7)$ patuh untuk minum obat.

Tabel 4. Karakteristik Responden Berdasarkan Kadar Glukosa Darah

\begin{tabular}{ccc}
\hline Kadar Gula Darah & $\mathrm{n}$ & $\%$ \\
\hline Tinggi & 28 & 60,9 \\
Normal & 18 & 39,1 \\
\hline
\end{tabular}

Tabel 4. menunjukkan bahwa sebagian besar responden $(60,9 \%)$ memiliki kadar glukosa darah tinggi. 
Tabel 5. Hubungan Kepatuhan Diet, Aktivitas Fisik dan Minum Obat dengan Kadar Gula Darah Sewaktu.

\begin{tabular}{|c|c|c|c|c|c|c|c|c|}
\hline \multirow[t]{3}{*}{ Variabel } & \multicolumn{4}{|c|}{ Kadar Gula Darah } & \multirow{3}{*}{ Rerata } & \multirow{3}{*}{$\mathrm{p}$ value } & \multirow{3}{*}{ OR } & \multirow{3}{*}{ CI } \\
\hline & \multicolumn{2}{|c|}{ Normal } & \multicolumn{2}{|c|}{ Tinggi } & & & & \\
\hline & $\mathrm{n}$ & $\%$ & $\mathrm{n}$ & $\%$ & & & & \\
\hline \multicolumn{9}{|l|}{ Kepatuhan Diet } \\
\hline Patuh & 15 & 32,6 & 7 & 15,2 & 196 & 0,000 & 15,343 & $3,327-67,636$ \\
\hline Tidak Patuh & 3 & 6,5 & 21 & 45,7 & & & & \\
\hline \multicolumn{9}{|l|}{ Kepatuhan } \\
\hline Aktivitas Fisik & 8 & 17,4 & 11 & 23,9 & 268 & 0,729 & 1,236 & $0,372-4,104$ \\
\hline Patuh & 10 & 21,7 & 17 & 37,0 & & & & \\
\hline \multicolumn{9}{|l|}{ Tidak Patuh } \\
\hline \multicolumn{9}{|l|}{ Kepatuhan } \\
\hline Minum Obat & 14 & 30,4 & 13 & 28,3 & 212 & 0,035 & 4,038 & $1,061-15,370$ \\
\hline Patuh & 4 & 8,7 & 15 & 32,6 & & & & \\
\hline Tidak Patuh & & & & & & & & \\
\hline
\end{tabular}

Tabel 5. menunjukkan bahwa responden yang patuh terhadap diet memiliki kadar gula darah rerata 196 g.\%. dengan $p 0,000$, ada hubungan yang signifikan antara tingkat kepatuhan diet dengan kadar gula darah didapatkan $O R \quad 15,343$, CI 3,32767,636, artinya pasien DM suku rejang yang patuh terhadap diet berisiko $15 \mathrm{kali}$ lebih besar akan mengalami kadar gula darah normal dibandingkan dengan yang tidak patuh.

Responden yang patuh terhadap aktivitas fisik memiliki rerata (268 g.\%) dengan $p$ 0,729 , tidak ada hubungan antara aktivitas fisik dengan kadar gula darah, didapatkan
OR 1,236, CI 0,372-4,104 artinya pasien DM suku rejang yang patuh pada aktivitas fisik berisiko 1 kali lebih besar akan mengalami kadar glukosa darah normal dibandingkan dengan yang tidak patuh.

Responden yang patuh minum obat memiliki rerata 212 g.\% dengan $p \quad 0,035$, ada hubungan yang signifikan antara minum obat dengan kadar gula darah, didapatkan $O R$ 4,038, $C I$ 1,061-15,370, artinya pasien DM suku rejang yang patuh minum obat berisiko 4 kali lebih besar akan mengalami kadar glukosa darah normal dibandingkan dengan yang tidak patuh. 
Tabel 6. Hasil Analisis Multi Variat Kadar Glukosa Darah dengan Kepatuhan Diet, Aktivitas Fisik, dan Kepatuhan Minum Obat

\begin{tabular}{lcccc}
\hline Variabel & Nilai $p$ awal & \multicolumn{2}{c}{ Nilai $p$ tahap eliminasi } & \multirow{2}{*}{ Odds Ratio } \\
\cline { 3 - 4 } & & Model 1 & Model 2 & \\
\hline Kepatuhan Diet & 0,000 & 0,000 & 0,001 & 2,14 \\
Aktivitas fisik & 0,729 & 0,966 & 0,792 & 4,24 \\
Kepatuhan minum Obat & 0,035 & 0,033 & 0,042 & 4,49 \\
\hline
\end{tabular}

Setelah dilakukan analisis multivariat menggunakan statistik regresi logistik, variabel kepatuhan diet memiliki hubungan yang bermakna secara statistik nilai $\mathrm{p}$ pada model awal 0,000, dan pada model ke 2 nilai p 0,$001 ; O R$ 2,14. Variabel aktivitas fisik tidak berhubungan yang bermakna secara statistik nilai $p$ awal 0,729 , nilai $p$

\section{PEMBAHASAN}

Pendekatan tanpa obat pada dasarnya merupakan penatalaksanaan atau pengelolaan pada penderita DM, pengelolaan tersebut dimulai pengaturan makan (diet) sesuai kebutuhan kalori, olah raga dengan latihan fisik yang cukup selama beberapa waktu. Obat diberikan jika kadar gula darah belum/tidak memenuhi kadar sasaran metabolik yang diharapkan atau dikatakan kurang efektif, maka pendekatan dengan obat dapat dilakukan, obat yang diberikan adalah obat hipoglikemik oral (OHO) atau dapat diberikan suntikan insulin sesuai dengan dosis atau indikasi (Wahidiyah, 2010). Penatalaksanaan ini perlu dipatuhi oleh pasien DM.

Kepatuhan (adherence) dapat artikan sebagai tingkatan perilaku seseorang yaitu (kemampuan atau pengetahuan, sikap dan tindakan) penderita diabetes dalam mendapatkan pengobatan, mematuhi aturan model 1 adalah 0,966 dan nilai $p$ pada model 2 adalah 0,792. Variabel kepatuhan minum obat memiliki hubungan yang bermakna secara statistik nilai $\mathrm{p}$ model awal 0,035 nilai p model 1 adalah 0,033 dan nilai p pada model 2 adalah 0,042 , dan OR.4,49.

diet, olah raga, dan atau merubah gaya hidup yang di rekomendasikan oleh pemberi pelayanan kesehatan. Namun beberapa faktor ini dapat mempengaruhi perubahan perilaku penderita diabetes untuk menjadi patuh atau sebaliknya menjadi tidak patuh terhadap program pengobatan, yang diantaranya dapat dipengaruhi oleh faktor predisposisi, dan faktor pendukung serta faktor pendorong. Faktor utamanya adalah faktor predisposisi dimana faktor ini merupakan faktor yang terdapat didalam diri individu yang terwujud dalam bentuk pengetahuan, persepsi, kepercayaan dan keyakinan, dan nilai-nilai serta sikap. Sedangkan ketidakpatuhan seseorang bisa dipengaruhi oleh pemahaman dan interaksi antara si pemberi informasi dan si penerima informasi, dan yang tak kalah pentingnya adalah kualitas dari interaksi pemberi dan penerima informasi tersebut (Notoatmodjo, 2010). 
Hasil penelitian ini mengidentifikasi bahwa ada 2 variabel yang berpengaruh terhadap kadar glukosa darah pada pasien diabetes mellitus suku rejang yaitu variabel kepatuhan diet dan kepatuhan minum obat, sedangkan variabel aktivitas fisik tidak berpengaruh terhadap kadar glukosa darah pasien DM suku rejang. Berikut ini akan dibahas masing-masing pengaruh variabel terhadap kadar glukosa darah pasien DM suku rejang.

\section{Pengaruh Kepatuhan Diet dengan Kadar Glukosa Darah}

Hasil analisis univariat menunjukkan bahwa sebagian besar responden tidak patuh pada diet $(52,2 \%)$. Pada analisis bivariat dengan menggunakan uji Chi Square menunjukkan terdapat hubungan yang bermakna secara statisktik antara kepatuhan diet dengan kadar glukosa sewaktu $\mathrm{p}=0,000$, OR 15,343 CI 3,32767,636, artinya pasien Suku Rejang dengan DM yang patuh terhadap program diet akan mengalami kadar gula darah sewaktu normal sebanyak 15 kali lebih tinggi dibandingkan dengan yang tidak patuh.

Hasil analisis multivariat juga menunjukkan adanya hubungan yang bermakna secara statistik antara kepatuhan program diet dengan kadar glukosa sewaktu p 0,001 CI 2,14. Artinya pasien DM suku rejang yang patuh terhadap diet dapat menjadikan kadar glukosa darah sewaktu normal sebanyak 2,14 kali dibandingkan dengan orang yang tidak patuh terhadap program diet.

Penelitian ini memiliki kesamaan dengan temuan Febriani (2014) yang mengidentifikasi bahwa terdapat hubungan antara kepatuhan diet dengan kadar gula darah sewaktu pada pasien diabetes mellitus tipe 2. Hasil penelitian ini juga memiliki kesamaan dengan temuan Astari (2017) yang mengidentifikasi bahwa terdapat hubungan yang bermakna antara terapi diet berkontribusi terhadap kadar glukosa darah. Hasil penelitian ini didukung oleh temuan Astuti (2017), yang menyatakan bahwa terdapat hubungan antara kepatuhan diet DM dengan tingkat kadar gula darah $(\mathrm{r}=-0,421)$. Hasil uji statistik menunjukkan nilai signifikan dari pengukuran minggu pertama hingga keempat $(p=0,021)$. Negatif artinya, semakin patuh pasien terhadap diet DM, maka dapat menjaga kadar gula darahnya atau terkontrol.

\section{Menurut American Diabetes Association} (2019) terapi diet/ nutrisi pada pasien DM bertujuan untuk meningkatkan pola makan yang sehat, makanan bervariasi dan porsi yang cukup, sehingga dapat menjaga berat badan, mengontrol kadar gula darah, tekanan darah dan lemak, serta mencegah komplikasi diabetes, memenuhi kebutuhan nutrisi dengan memperhatikan pribadi dan budaya, akses mendapatkan makanan, keinginan ataupun hambatan untuk berubah, mempertahankan kesukaan makanan tanpa menghakimi, dan menyediakan alat praktis untuk pola makan yang sehat.

Terapi diet merupakan salah satu pilar dari penatalaksanaan diabetes mellitus sehingga kepatuhan terhadap terapi diet sangat penting. Namun merupakan tantangan yang sulit bagi diabetes dalam mengontrol kepatuhan diet. Beberapa faktor yang dapat mempengaruhi kepatuhan diet penderita diabetes, seperti masalah psikologis/ kejiwaan yaitu gangguan makan, gangguan 
afektif, dan konflik dalam keluarga, serta tekanan/stres. Oleh karena itu diperlukan pendidikan kesehatan terutama kepada keluarga, karena keluarga diharapkan dapat memberikan dorongan dan perhatian pada penderita diabetes dalam kepatuhan. Pendidikan kesehatan merupakan salah satu faktor yang penting untuk menjaga kepatuhan pasien (Perkeni, 2015).

Komposisi makanan diet pada penderita diabetes dapat memadai dengan memperhatikan pemberian kalori yang cukup sesuai kebutuhan, memperhatikan jumlah makanan dan jenis makanan.

Jumlah makanan yang dikonsumsi harus disesuaikan dengan kebutuhan kalori penderita diabetes setiap harinya. Komposisi diet yang dianjurkan pada penderita diabetes adalah karbohidrat sebesar 45-65\% dari keseluruhan/total kalori yang dibutuhkan setiap harinya, dan protein yang dianjurkan sebesar 10-20\% dari total kalori, dan untuk lemak diperlukan sebanyak 20-25\% dari total kalori, serta serat \pm 25 gram adalah serat yang mempunyai nilai gizi. Selain itu, penting juga untuk mengatur jadwal makan karena jarak antar waktu makan yang teratur akan membuat pankreas dapat melakukan fungsinya dengan baik dan lebih teratur (Perkeni, 2015).

\section{Pengaruh Aktivitas Fisik dengan Kadar Glukosa Darah}

Dari hasil analisis univariat terdapat 19 orang $(41,3 \%)$ responden yang patuh terhadap kegiatan aktivitas fisik. Rerata kadar gula darah sewaktu responden yang patuh terhadap aktivitas fisik yaitu 268 gr $\%$, lebih tinggi dari rerata kadar glukosa darah sewaktu responden yang patuh terhadap diet yaitu 196 gr\% dan yang patuh terhadap minum obat yaitu 212 gr\%. Pada analisis bivariat menunjukkan bahwa kepatuhan terhadap aktivitas fisik tidak berhubungan yang bermakna secara statistik p 0,729, OR 1,236, CI 0,372-4,104. Artinya orang yang patuh terhadap aktivitas fisik tidak berpengaruh terhadap kadar gula darah sewaktu. Hasil analisis multivariat juga menunjukkan juga bahwa tidak ada hubungan antara kepatuhan aktivitas fisik dengan kadar gula darah sewaktu p 0,792.

Hasil ini berbeda dengan hasil penelitian Astari (2017) disebutkan bahwa responden yang melakukan aktivitas fisik yang cukup sebagian besar yaitu sebanyak 55,8\% dan sebagian kecil responden dengan aktivitas fisik kurang. Hasil penelitian ini juga berbeda dengan penelitian yang yang dilakukan oleh Sujaya (2009), yang penelitiannya dilakukan di RS Tabanan Bali. Dari hasil penelitiannya mengidentifikasi bahwa aktivitas fisik merupakan variabel yang berhubungan dengan DM tipe 2. Disebutkan bahwa orang yang melakukan aktivitas fisiknya rendah mempunyai risiko 4,36 kali lebih besar dibanding dengan orang yang mempunyai aktivitas fisik tinggi untuk dapat menderita DM tipe 2.

Hasil penelitian ini juga berbeda dengan temuan Anani (2012), yang mengidentifikasi bahwa terdapat hubungan yang bermakna secara statistik antara aktivitas fisik $(\mathrm{p}=0,012)$ dengan kondisi glukosa darah. Perbedaan ini dapat saja terjadi karena aktivitas fisik yang cukup akan meningkatkan sensitifitas insulin. Individu yang aktif akan memiliki kadar insulin dan profil glukosa yang lebih baik dari pada individu yang tidak aktif.

Secara teori aktivitas fisik dapat mengontrol gula darah. Pada saat 
beraktivitas fisik glukosa akan diubah menjadi energi. Seseorang yang melakukan aktivitas fisik dapat mengakibatkan insulin semakin meningkat sehingga peningkatan ini menyebabkan kadar gula dalam darah akan berkurang. Sedangkan pada orang yang jarang melakukan aktivitas atau kurang berolahraga yang cukup, mengakibatkan zat makanan yang masuk ke dalam tubuh tidak dibakar namun ditimbun dalam tubuh sebagai lemak dan gula. (Perkeni 2015).

Melakukan aktivitas jasmani atau latihan secara rutin dapat menurunkan resistensi insulin (Jelleyman, Yates, O’Donovan G, et al., 2015). Hal tersebut dapat meningkatkan kerja insulin dan mempercepat pengangkutan glukosa masuk ke dalam sel untuk memenuhi kebutuhan energi. Olahraga dapat dilakukan secara teratur yaitu 3- 4 kali dalam seminggu dengan waktu yang dibutuhkan untuk olah raga durasinya kurang lebih 30 menit, ini dapat menjaga kebugaran serta dapat menurunkan berat badan. Selain itu, berolahraga secara teratur bisa memperbaiki sensitivitas insulin, hal ini akan memperbaiki kendali glukosa dalam darah. Latihan aktivitas jasmani sebaiknya yang bersifat aerobik seperti jalan kaki, bersepeda santai, dan jogging, serta berenang. Latihan jasmani atau aktivitas dapat disesuaikan dengan kondisi penyakit, untuk yang relatif sehat, intensitas latihan jasmani bisa ditingkatkan, sementara yang sudah mendapatkan komplikasi diabetes melitus dapat dikurangi (Kurniawan \& Wuryaningsih, 2016).

Meskipun pada penelitian tidak menunjukkan hubungan aktivitas fisik terhadap kadar gula darah namun latihan sebaiknya tetap dilakukan secara rutin. Prevalensi diabetes mellitus mencapai 2-4 kali lipat dapat terjadi pada seseorang yang kurang aktif beraktifitas dibandingkan dengan individu yang aktif dalam beraktifitas. Dapat dikatakan bahwa semakin kurang beraktifitas fisik seseorang, maka semakin mudah seseorang terkena diabetes. Aktifitas fisik atau olahraga dapat membantu mengontrol berat badan. Manfaat lainnya glukosa dalam darah akan dibakar menjadi energi, sehingga sel-sel tubuh menjadi lebih sensitif terhadap insulin. Selain itu, aktifitas fisik yang teratur dapat juga melancarkan peredaran darah dalam tubuh, dan dapat menurunkan faktor risiko terjadinya seseorang mengalami diabetes mellitus ( Perkeni, 2015).

\section{Kepatuhan Minum Obat dengan Kadar Glukosa Darah}

Dari hasil analisis univariat diketahui bahwa 27 orang $(58,7 \%)$ responden patuh terhadap program minum obat. Rerata kadar glukosa darah sewaktu pasien yang patuh terhadap minum obat yaitu 240 gr\%. Hasil analisis bivariat menunjukkan terdapat hubungan yang bermakna secara statistik antara kepatuhan minum obat dengan kadar gula darah sewaktu yaitu $p$ =0,035, OR =4,038, $C I=1,061-15,370$. Artinya orang yang patuh terhadap minum obat akan mengalami kadar gluksa darah normal sebanyak 4 kali lebih tinggi dibandingkan dengan orang yang tidak patuh terhadap minum obat. Hasil analisis multivariat masih menunjukkan hubungan yang bermakna secara statistk antara kepatuhan minum obat dengan kadar glukosa darah sewaktu $p=0,042, C I=4,49$. 
Hasil penelitian ini sesuai dengan penelitian yang dilakukan oleh Mei (2013) dijelaskan bahwa sebanyak $62,8 \%$ responden mereka menggunakan obat DM. Penggunaan obatobatan adalah salah satu pilar penatalaksanaan diabetes mellitus, dan berkontribusi terhadap pengendalian kadar glukosa dalam darah. Kadar glukosa dalam darah dapat dipengaruhi oleh penggunaan obat hipoglikemia oral maupun dengan insulin. Adapun mekanisme kerja obat adalah dengan merangsang kelenjar pankreas untuk dapat meningkatkan produksi insulin, dan menurunkan produksi glukosa dalam hepar, serta menghambat pencernaan karbohidrat sehingga hal ini dapat mengurangi absorbsi glukosa dan dapat merangsang reseptor insulin (Perkeni, 2011).

Hasil penelitian ini memiliki kesamaan dengan temuan Astari (2017) yang menemukan bahwa terdapat hubungan antara kepatuhan terapi diet dan kadar gula darah puasa pada penderita diabetes mellitus tipe 2 di wilayah kerja Puskesmas Purnama Pontianak. Perbedaan hasil penelitian ini dengan penelitian sebelumnya adalah pada indikator dalam pengukuran kadar glukosa darah. Pada penelitian Astari (2017) dijelaskan kadar glukosa darah yang diukur adalah kadar glukosa darah puasa.

Terapi farmakologis terdiri dari pemberian obat oral dan pemberian dalam bentuk suntikan. Terapi farmakologis diberikan bersamaan dengan pendidikan kesehatan dalam peningkatan pengetahuan pasien, yaitu pengaturan makan dan latihan jasmani. Dalam Konsensus Pengelolaan dan Pencegahan DM tipe 2 di Indonesia 2011, dijelaskan penatalaksanaan dan pengelolaan DM dititik beratkan pada 4 pilar penatalaksanaan DM, yaitu: 1) edukasi, 2) terapi gizi medis, 3) latihan jasmani dan 4) intervensi farmakologis (Perkeni 2011).

Menurut Black dan Hawks (2010), insulin bekerja menurunkan kadar glukosa darah dengan membantu transpor glukosa dari darah ke dalam sel, sehingga berpengaruh pada metabolisme di dalam tubuh. Kekurangan insulin dapat menyebabkan glukosa darah tidak dapat masuk atau terhambat masuk ke dalam sel, sehingga glukosa darah akan menjadi meningkat, dan sebaliknya sel-sel tubuh dapat kekurangan bahan sumber energi sehingga tidak dapat memproduksi energi sebagaimana seharusnya.

Perilaku keteraturan konsumsi obat antidiabetik menjadi salah satu upaya dalam pengendalian glukosa darah ataupun menghindari komplikasi yang dapat ditimbulkannya. Penderita diabetes diharapkan patuh dalam mengkonsumsi obat. Jika penderita DM tidak patuh dalam melaksanakan program pengobatan yang telah ditetapkan oleh dokter atau petugas kesehatan lainnya, maka dapat berakibat memperburuk kondisi penyakit yang dideritanya (Tohari, Cahyati, \& Zainafree, 2015).

\section{KESIMPULAN}

Terdapat hubungan yang bermakna secara statistik antara kepatuhan diet, kepatuhan minum obat terhadap kadar glukosa darah sewaktu pasien DM tipe 2 suku Rejang di Kabupaten Rejang Lebong tahun 2018. Diharapkan pasien DM untuk selalu mematuhi diet, aktivitas fisik dan pengobatan. 


\section{DAFTAR PUSTAKA}

Aditama, T. Y. (2013). Diabetes melitus penyebab kematian nomor enam. Diunduh dari http://www.depkes.go.id/article/print/23 83/diabetes-melitus-penyebab-kematiannomor-6-di-dunia-kemenkes-tawarkansolusi-cerdik-melalui-posbindu.html.

American Diabetes Association. (2019). Lifestlye management: Standards of medical care in diabetes 2019. Diabetes Care, $\quad 42(1), \quad$ S46-S60. https://doi.org/10.2337/dc19-S005.

http://care.diabetesjournals.org/content/4 2/Supplement_1/S46.

Anani, S. (2012). Hubungan antara perilaku pengendalian diabetes dan kadar glukosa darah pasien rawat jalan diabetes mellitus (studi kasus di RSUD Arjawinangun Kabupaten Cirebon). Diunduh dari http://eprints.undip.ac.id/38380/.

Astari, R. (2017). Hubungan antara kepatuhan terapi diet dan kadar gula darah puasa pada penderita diabetes melitus tipe 2 di wilayah kerja puskesmas purnama pontianak. Diunduh dari https://www.neliti.com/id/publications/1 94084/hubungan-antara-kepatuhanterapi-diet-dan-kadar-gula-darah-puasapada-penderita.

Astuti, L. (2017). Hubungan Kepatuhan diet dengan Kadar glukosa darah pasien DM kelompok persada di RS PKU Muhammadiyah Yogyakarta. Diunduh dari

http://digilib.unisayogya.ac.id/id/id/eprin $\mathrm{t} / 3945$.

Badan Penelitian dan Pengembangan Kesehatan Departemen Kesehatan RI. (2018). Laporan riset kesehatan dasar (Riskesdas) 2018. Jakarta.

Black, J. M. \& Hawks, J. H. (2010). Medical surgical nursing: Clinical management for positive outcomes. ( $8^{\text {th }} \quad$ ed.). Singapore: Elsevier.
Centers for Disease Control and Prevention, National Diabetes Statistics Report. (2017). Atlanta, GA, USA, centers for disease control and prevention, US dept of health and human services, 2017. Diunduh dari https://www.cdc.gov/diabetes/pdfs/data/ statistics/national-diabetes-statisticsreport.pdf.

Dahlan, M. S. (2012). Analisis multivariat regresi logistik. Jakarta: Epidemiologi Indonesia.

Dinas Kesehatan Propinsi Bengkulu. (2015). Profil kesehatan propinsi bengkulu Tahun 2014. Bengkulu

Febriani, R. (2014). Hubungan Kepatuhan Diet Dengan Kadar Gula Darah Sewaktu Pada Pasglien Diabetes Melitus Tipe 2 Di Rawat Inap RSUD Sukoharjo. Diunduh dari http://eprints.ums.ac.id/28060/.

Jelleyman, C., Yates, T., O’Donovan G., et al. (2015). The effects of high-intensity interval training on glucose regulation and insulin resistance: a meta-analysis. Obes Rev, 16, 942-961. doi:10.1111/obr.12317.

Kurniawan, A. A., \& Wuryaningsih, Y. N. (2016). Rekomendasi latihan fisik untuk diabetes mellitus tipe 2. BIKDW, 1(3). Doi.

http://dx.doi.org/10.21460/bikdw.v1i3.22

Mei, C. (2013). faktor-faktor yang berhubungan dengan pengendalian kadar glukosa darah pasien diabetes melitus tipe 2 rawat jalan di poliklinik penyakit dalam RSJ Prof. Dr. Soerojo Magelang Tahun 2013, Magelang. (Skripsi).

Notoatmodjo, S. (2010). Promosi kesehatan: Teori dan aplikasi. Jakarta: Rineka Cipta.

PERKENI. (2011). Konsensus pengelolaan dan pencegahan diabetes melitus tipe 2 di indonesia. Jakarta. PB PERKENI. 
PERKENI. (2015). Konsensus pengelolaan dan pencegahan diabetes melitus tipe 2 di indonesia. Jakarta. Diunduh dari https://www.scribd.com/doc/310474800/ Perkeni-Diabetes-Mellitus.

Sujaya, I. N. (2009). Pola konsumsi makanan tradisional bali sebagai faktor risiko diabetes mellitus tipe 2 di tabanan. Jurnal Skala Husada, 5(1).

Tohari, Cahyati, Zainafree. (2015). Hubungan modifikasi gaya hidup dan kepatuhan konsumsi obat antidibetik dengan kadar glukosa darah pada penderita Diabetes militus tipe 2 di RS QIM Batang. http://journal.unnes.ac.id/sju/index.php/u jph.

USU. (2014). Formulir food recall. Diunduh dari

http://repository.usu.ac.id/bitstream/han dle/123456789/62227/Appendix.pdf?seq uence $=1 \&$ isAllowed $=\mathrm{y}$.

Wahidiyah. (2010), Hubungan antara tingkat pengetahuan, sikap dan keikutsertaan penyuluhan gizi dengan perilaku diet, https://www.neliti.com/publications/187 $53 /$.

Whiting, L., Guariguata, C., Weil, and Shaw, J. (2011). IDF diabetes atlas: Global estimates of the prevalence of diabetes for 2011 and 2030. Diabetes Research and Clinical Practice, 94(3), 311-321. 